\title{
Patient safety in the operating theatre
}

\begin{abstract}
In connection with medical services provided, many patients are exposed to harm that may lead to permanent health impairment, hospitalisation, extended hospital stay or even death. Adverse events are reported and are the result of a complex nature of current healthcare systems, in which effective therapy and treatment outcomes of every patient depend on numerous factors, and not only on competencies of individual healthcare professionals.

Individual healthcare professionals can contribute to improving the safety of care by establishing respectful relationships with patients, following procedures, learning from mistakes, and communicating effectively with other members of the therapeutic team. This also decreases costs associated with reduction of harm sustained by patients. Reporting and analysis of errors may help identify major factors that have contributed to their occurrence. In order to consider changes that could prevent errors, at first it is necessary to learn about factors that led to them. An operating theatre is the heart of every hospital. It is where complex and highly specialized surgical procedures are performed in line with state-of-the-art procedures and applicable standards. It is also where employees of various wards meet to perform their crucial tasks that save lives.

Patient's well-being is a paramount value for a therapeutic team working in the operating theatre. The main goal of surgical nurse is, in turn, to ensure a holistic and individual approach to the patient in accordance with applicable law, procedures and recommendations.
\end{abstract}

Keywords: patient safety, operating theatre, adverse event.

DOI: $10.2478 /$ pjph-2021-0001

\section{INTRODUCTION}

Patient safety should be given priority in national, regional and local politics and health programmes. Every patient has the right to receive health services that correspond to current medical knowledge. A patient has also a right to be safe and enjoy safe conditions while being provided health services [1].

Approximately 234 million of surgeries are carried out worldwide per year, which means that one in twenty five person of the world's population undergoes surgery in a given year [2]. The number of surgeries performed is nearly twice as high as the number of births. It is also significantly higher in highly developed regions as compared to poor countries.

Patient safety in the hospital is one of the most elementary goals of professional care. Most recent global studies report that 770 thousand patients are involved in various accidents every year that result from medical errors. According to ICA$\mathrm{HO}$ the following most common adverse events can be distinguished: intra- and postoperative complications, wrong-site surgery, administration of a wrong drug, suicide in a hospital, deaths resulting from delayed access to health care, perinatal injuries and deaths, deaths caused by leaving against medical advice, assault, rape and killing $[3,4]$.
An operating theatre is where complex and highly specialized surgical procedures are performed in line with state-of-theart procedures and applicable standards. This is why surgical staff is required to constantly improve their qualifications and pursue personal growth. Work and competence of therapeutic team, quantity and quality of medical equipment all have impact on the quality of surgeries performed. Awaiting surgery is a difficult experience for patients. This is why the most significant issue is to ensure maximum safety using specialist knowledge of the staff and capability of the operating theatre. Knowledge of standards, ongoing staff education, sufficient number of employees, proper interpersonal communication and appropriate resources are the most important elements of good and competent care in the operating theatre. It seems that perioperative safety may be improved if empathetic well-trained nurses, who play an important role in therapeutic team, are employed.

The objective of the article is to draw attention to the role of therapeutic team in ensuring safety of a patient in the operating theatre in pre-, peri- and postoperative period, as well as to point out the large percentage of postoperative complications that is still too high and failure to record adverse events.

In connection with medical services provided, a significant number of patients is exposed to harm that leads to permanent

\footnotetext{
${ }^{1}$ Chair and Department of General and Transplantation Surgery, Transplantation Institute, Warsaw, Poland

${ }^{2}$ Division of Surgical and Transplantation Nursing, and Extracorporeal Treatment, Medical University of Warsaw, Poland
} 
health impairment, hospitalisation, extended hospital stay or even death. Adverse events are reported and are the result of a complex nature of current healthcare systems, in which effective therapy and treatment outcomes of every patient depend on numerous factors, and not only on competencies of individual healthcare professionals.

Operating theatre is one of the most important organisational unit in a hospital but also entails an increased epidemiological risk. It is a place where procedures limiting the risk of microbial transmission and their spread in the environment should be strictly observed. Therefore, place of the operating theatre in the structure and organisation of a hospital is clearly defined. It is also where employees of various wards meet to perform their crucial tasks that save lives. It is favourable to reduce the number of employees who have contact with a patient to the so-called "permanent staff" (scrub nurse, assisting nurse, surgical team and anaesthesia team and support staff) within one surgical room of given operating theatre as this may have a substantial effect on the safety of an operated patient.

Regulations concerning functioning of operating theatres have changed in connection with accession to the European Union. Requirements pertain to a distinction made between traffic of "clean" employees, patients and resources and "dirty" instruments and scrubs. They also impose an obligation to organise sluice rooms for employees and patients as well as rooms adapted for storing surgical materials.

\section{Regulation of the Minister of Health of 26 June 2012 provides for detailed requirements to be met by operating theatre rooms}

Many hospitals upgrade their operating rooms to bring them in line with the Regulation. These upgrades include, but are not limited to, installing air conditioning, laminar aseptic air supply in the operative field, investing in a good quality operating equipment (e.g. lamps or operating tables) and replacing standard building materials into the ones enabling greater asepticity (e.g. stainless steel walls and doors). They are expensive but improve treatment quality, e.g. by reducing the percentage of postoperative infections.

It should be noted that air conditioning increases working comfort but, if not maintained and supervised correctly, it may contribute to respiratory infections in both employees and patients as well as infections of surgical wounds. Usually surgical nurses regularly check air quality in operating rooms by placing plates with appropriate media in the same areas, which are sent to a microbiology laboratory after a specific time.

In order to ensure the high quality of medical services rendered by staff who work in operating theatres, it is necessary to create good working conditions allowing everyone to observe asepsis and hygiene principles, prevent severe infections and other complications that extend patient's stay at the hospital.

The main goal of a therapeutic team working in the operating theatre is to ensure a comprehensive and tailored approach to a patient in accordance with state-of-the-art medical knowledge, available methods and measures as well as in line with professional ethics, applicable law, procedures and recommendations. An appropriate number of surgical nurses that corresponds to the needs of given operating theatre must be employed to guarantee patient safety and professional care. The Regulation of the Minister of Health dated 2018 imposed an obligation on healthcare institutions to ensure "at least two surgical nurses per each operating table" [5].
A number of tasks of surgical nurses is divided between a scrub nurse and an assisting nurse. Their tasks differ, but close cooperation is necessary. Roles and responsibilities of a surgical nurse are to prepare operating theatre in a comprehensive, independent, professional, expert manner and as planned, and to assist when it is conduced and supervised. Both a scrub nurse and an assisting nurse provide comprehensive care for the patient during surgery, are responsible for safety of procedures and activities performed on the patient, in particular on those operated under general anaesthesia. This requires a nurse to be particularly focused as these patients are not able to respond and defend themselves.

All surgical procedures, regardless of specialty, are invasive procedures that entail a high risk of nosocomial infections. They pose a substantial risk to health and life of both a patient and staff. This is why it is crucial to know the standards and follow medical procedures. Preoperative preparation is of particular importance.

\section{Preparing patients to undergo surgery}

In this field, activities directly related to patient care and those that do not require a direct care can be distinguished. The latter ones are also of great importance as many preparatory activities that are closely related to the proper conduct of surgeries take place during afternoon and night shifts, when the staff is on-call (it is ready for surgeries performed on emergency basis). A surgery can be elective (patient's condition is not life threatening at present, but requires surgical intervention) or performed on emergency basis (symptoms exacerbate and may become life threatening). In case of elective surgeries patients can be prepared for a surgery, both physically and mentally.

In perioperative period each patient experiences strong emotions associated with fear of an unknown medical procedure and care provided by third parties, fear of pain and possible disability. Each disease, and even more so a serious disease requiring surgical intervention, causes stress due to unpredictability, often a sudden onset and its individual nature. Hospital stay entails loss of privacy, violation of intimacy, the need to comply with strict regulations applicable at given ward as well as staying away from home, job, and family and friends [6].

Hospital staff must take these aspects into account, not only by carefully performing medical procedures but also by establishing respectful relationships with patients, following procedures, learning from mistakes, and communicating effectively with other members of the therapeutic team. Individual healthcare professionals can contribute to improving the safety of care by providing accurate information about future procedures, the perioperative period and by having a positive influence on patient's mental condition in order to provide them with a broadly understood safety. It is extremely important to talk with a patient and meticulously explain the goal and course of additional tests and any possible complications. Consultation with an anaesthetist who, after examining the patient, orders premedication and decides on anaesthesia for given surgery, should be a fixed part of preparation before a surgery. When a patient receives all information and his/her doubts are cleared up, fear is reduced and a patient accepts suggested procedures.

Patients undergoing surgical procedures are at risk of perioperative complications associated with surgical positions typical of given specialty. Therefore, it is very important to not 
only comfortably but also safely place patients on a surgical table so that they do not experience discomfort resulting from a forced position and do not develop complications associated with pressure, nerve paralysis and soft tissue damage. Before surgery, it is necessary to prepare the equipment of the operating table to be used during given surgery, which should also correspond to possible patient's problems, condition of their musculoskeletal system, or body deformation. Lying in a forced position for a long time may aggravate patient's physical disorders. Patient should also be secured against chafing (body parts must not be in direct contact). As far as bedsore prevention is concerned, pads, gel wheels and rollers should be placed in areas most susceptible to such lesions (e.g. heels).

Surgeries can be long and extensive, which is why patients lose great amount of heat. Furthermore, thermoregulation is disturbed as a result of anaesthetic agents used in general anaesthesia. In such cases, a patient should be placed on a warming mattress and covered with a disposable sheet or a warming blanket, if required, in order to maintain normothermia.

It is extremely important to protect a patient against burns of skin or mucosa caused by a disinfecting agent and against electric shock and burns associated with surgical diathermy. For this purpose, a patient should be secured against contact with electrically conductive objects (e.g. metal parts of the operating table). A passive plate should be placed on a clean and dry skin of patient's thigh.

No one should forget about securing a patient against sliding off the operating table when table's position is changed during the procedure. A patient should be strapped to the operating table with a belt which additionally enables safe awaking after the surgery (uncontrolled movements during immediate recovery from anaesthesia). The operating team must pay particular attention to respecting patient's dignity during every activity involving him/her.

One of the very important tasks resting with the surgical team during each surgery is to control instruments and quantity of surgical materials used during the procedure. It is of particular importance during very long surgeries, often with surgical team being switched. Loss of surgical material in the operative field may lead to serious complications. Such errors may pose a direct threat to patient's health and life as well as may constitute a basis for claims filed by an aggrieved party, and civil or even criminal liability.

Surgical materials should be inspected several times, i.e.:

- before the surgery;

- when surgical nurses switch at the operating table;

- when surgical materials are placed in the sterile area;

- before closing the body cavities;

- directly before end of the procedure.

Patient safety entails also awareness of risks and hazards stemming from professional autonomy, assessment of own behaviours and consolidation of team work. It is also necessary to dispel a myth that there are no errors. There is literally no healthcare facility in the world without any adverse events noted [7].

\section{Adverse events}

Any surgical procedure and anaesthesia carry a risk of postoperative complications. Many of them can be avoided since they result from organizational imperfections or human errors. Approximately 7 million of patients suffer from severe postoperative complications annually, and over a million of them dies during surgery or in the early postoperative period [8]. Sense of safety experienced by patients using medical services is determined by the level and quality of healthcare system. They can be evaluated as part of root cause analysis, monitoring of adverse event reporting [9]. The exact number of adverse events in Poland that occur in the healthcare system is unknown as they are rarely reported. A medical error may take place when a doctor, nurse or any other healthcare professional failed to exercise due diligence or did something falling outside their competence while treating or caring for a patient, which in turn results in loss of patient's health or life. Therefore, it is very important to be aware of the risk, control one's behaviour and follow procedures. Studies conducted so far and the Report of the National Institute of Health revealed that a hospital is a place where highly complex medical services are provided, thereby entailing a considerable risk. It is not possible to completely eliminate adverse events, but one should strive to reduce their frequency. Contemporary medicine must keep up with constant changes, creating a new patient care model. Parts of this model are associated with medical knowledge and procedures aimed at improving quality of medical services, and thus patient safety [11-13].

The so-called System Control Charts, such as perioperative control charts introduced in 2011 in all departments and treatment facilities in the entire Poland, as recommended by the Ministry of Health, are a great example of preventive action against medical errors [14]. Perioperative control chart should be placed in patient's medical records. It is filled by a "chart coordinator" in collaboration with the team. It is used to record individual management stages during patient's stay at the operating theatre, together with requirements imposed on team members that, if followed, will allow everyone for avoiding adverse events. The perioperative control chart is a tool supporting safety actions and consists of three parts. The first part contains information about patient's identity, surgery type and approach, possible known risks associated with the surgery and anaesthesia, and safety and performance of the equipment used. It is filled upon patient's admission at the operating theatre (and with his/her participation) before anaesthesia.

The second part briefly discusses the course of surgery, patient's condition, instrumentarium, preventive antibiotic therapy and imaging studies. A surgeon, an anaesthetist and a scrub nurse must re-confirm that the team is familiar with each other, and patient's identity, surgery type and approach must be confirmed by all of them. Part three is filled at the end of the surgery, before a surgeon leaves the room. It is used to confirm the type of surgery performed, compliant number of swabs and tools, condition of equipment used as well as to acknowledge that biological material collected is labelled accordingly. A postoperative management plan is also discussed. Perioperative control chart has a favourable effect on surgical outcomes and reduces number of complications. Progress in medicine, including access to state-of-the-art technologies, as well as better qualifications of healthcare professionals lead to a growth in the number of surgical procedures performed. Therefore, it is extremely difficult to ward adverse events off, such as a surgical site infection [15].

\section{Surgical site infection (SSI)}

Nosocomial infections, surgical site infections in particular, have serious consequences for surgical patients. They cause 
pain, suffering, extended hospitalisation, high treatment costs and often lead to re-operation. Surgical site infections (SSIs) account for $22 \%$ of all nosocomial infections and are reported in $38 \%$ of surgical patients. They are most frequently caused by patient's (endogenous) bacteria residing in and near the incision site [16].

WHO suggested in 2016 the following division of SSIs:

- superficial incisional SSIs (SSI-S) that develop within 30 days after the surgery and affect skin and subcutaneous tissue only;

- deep incisional SSIs (SSI-D) that also develop within 30 days after the surgery, unless an implant has been placed; in case of implant placement, this time is extended to 90 days; deep infection affects deeper soft tissues, e.g. fascia or muscle;

- organ/cavity infections (SSI-O) - if symptoms developed within 30 and 90 days after the surgery without and with implant placement, respectively, and they affect an anatomical part (e.g. an organ or a cavity) other than an incision site, opened or manipulated during a surgery $[17,18]$.

As far as areas of SSIs are concerned, the following ones can be distinguished: superficial infection of skin and subcutaneous tissue, deep infection affecting fascia and muscles, and involvement of an organ or a body cavity that is in direct contact with surgical site [18,19].

The following factors particularly increase the risk of SSIs: - very long surgeries prolonging the time a tissue is exposed;

- surgical site contamination - factors increasing the risk of endogenous contamination;

- ASA (American Society of Anaesthesiologists) classification system assessing the risk of major complications or death while under anaesthesia or thereafter - category 3, 4 and 5 .

Nowadays, a number of serious surgical infections is increasing due to various factors such as:

- more and more complex surgeries performed in the elderly with numerous concomitant diseases;

- progress in transplantation medicine, the inherent part of which being immunosuppression;

- placement of various types of implants (meshes, prostheses, etc.);

- surgeries on immunocompromised patients;

- use of broad-spectrum antibiotics which increases resistance.

Also microorganisms may be the cause of surgical site infections. These include:

- microbiota - susceptible to antibiotics;

- pathogens - resistant to antibiotics, difficult to eradicate, easily spreading in hospital setting;

- microorganisms residing in biofilm;

- infectious proteins (prions).

All surgical procedures are associated with high risk of viral infections transmitted, for example, through blood and direct contact: hepatitis B, hepatitis C, HIV, HPV. Being aware of infections and their sequelae, their causes, epidemiology, aetiology and symptoms is a prerequisite for their efficient control and effective prevention. The most important preventive measures include: compliance with hospital hygiene rules, including hand hygiene of medical personnel, use of protective clothing, decontamination of hospital rooms and appropriate medical waste management. The principles of asepsis are provided for in documents, the goal of which is to determine how to perform given tasks. These are standards which, if followed, guarantee a high level of care. Impeccable order kept in operating rooms and other rooms in the operating theatre is required to minimize the incidence of nosocomial infections. Therefore, it is absolutely necessary to follow the rules for proper cleaning of the operating room after each surgery and after elective procedures.

It is also very important to keep instruments sterile by observing the rules for handling dirty instruments, and cleaning, disinfecting and sterilising them accordingly. In order to meet the requirements for handling of surgical instruments, disposable and reusable equipment, operating theatres should benefit from professional services offered by modern sterile processing companies which are ISO-certified. Each sterilization process must be controlled by a biological indicator. Hand disinfection is another most effective method of infection prevention. Immediately before the surgery, surgeons and operating nurse must perform surgical hand preparation in line with PN-EN 12791:2005 "Surgical handrubbing technique".

Cleaned and rinsed hands should be dried with a disposable towel and rub a disinfecting agent using Ayliffe technique until dry.

It should be noted that hand skin will only be disinfected after rubbing, which means that certain forms of microorganisms may stay on its surface. That is why sterile scrubs and sterile surgical gloves should be put on immediately after this procedure. When putting on scrubs and gloves, care should be taken not to touch the sterile surface of scrubs and gloves with bare hands. Proper preparation and protection of the skin in the operative field are very important to secure incision site against migration of microorganisms, and thereby against possible SSI. Operative field is prepared immediately before the surgery. It is disinfected and incise drapes are placed in its area. Thick hair is preferably removed using surgical clippers. Skin in the operative field should not be shaved, as it promotes microtraumas and secondary skin infections, whereas hair removal products can trigger an allergic reaction.

Operative field is disinfected by an operating surgeon or an assistant surgeon, who are responsible for quality of disinfection and size of disinfected area. Disinfection should last approximately 3-5 minutes, until skin is dry. Disinfected surface should not be wiped dry so as to give the agent used sufficient time for its action. A disinfecting agent should exhibit a broad spectrum of action, short activity, short drying time, longterm biocidal activity in accordance with Polish and European standards.

It is required to use a disinfecting agent with a broad spectrum of biocidal activity and immediate action, and a dye to clearly mark disinfected area (or a different preparation if a patient is allergic to dry or any other of its ingredients). Ingredients of a disinfecting agent should not be inactivated in presence of organic substances (blood, wound drainage, body fluids) and must not cause irritation.

It is not possible to completely sterilise operative field using disinfecting agents. Surgical film is the best method for preparing operative field, apart from disinfection, that reduces the risk of surgical site infection. After being carefully stuck to skin in the operative field (following draping), it provides 
a sterile cover and keeps a number of microorganisms to the minimum in the operative field for a long time.

When the operative field becomes completely dry (a disinfecting agent has evaporated), it is draped to maintain aseptic conditions. Drapes must be medical devices compliant with directive 93/42/EEC and 89/686/EEC. Polish Standards PN EN 13 795-3+A1:2010 clearly define properties of drapes which are to protect operative field and secure a patient against infection. Drapes should correspond to the type of surgery, and patient's body should be covered in whole, except for the exact operative field. A number of various factors trigger nosocomial infections. Criteria for order of elective surgeries, inspection of suitability for use of medical devices and surgical materials (expiration date, packaging tightness, etc.), correct documentation, waste sorting and the role of infection commission should be mentioned.

Prevention of infections must become a priority for all healthcare employees and as such should constitute an important part of patient safety curricula.

However, expertise of the staff, being familiar with up-todate procedures and following sanitary regime, implementing appropriate standards and procedures are, by far, the most significant constituents of prevention of and fight with infections. It is worth mentioning nosocomial infections and medical errors resulting from work overload, poor organisation of work, lack of concentration and chronic fatigue. Fatigue impairs the coordinating function of nerve centres and reduces psychomotor efficiency, which directly affects work performance, and thereby patient safety [20].

\section{CONCLUSION}

1. The specific nature of what surgical nurses do, requires that at least two surgical nurses, a scrub nurse and an assisting nurse, be present during each surgery in the operating room.

2. Safety at work of operating nurses is a multidimensional issue and is mainly related to ensuring patient safety.

3. The operating team must pay particular attention to respecting patient's dignity during every activity involving a patient.

4. The entire perioperative care should be patient-oriented and consider their well-being and safety.

5. Work in the operating theatre should be performed in accordance with the standards, procedures and instructions developed based on current medical knowledge and research-based recommendations.

6. Nursing care at the operating theatre is a prelude for further postoperative care preventing postoperative complications.

7. Standards and procedures play an important role in providing proper care and help reduce intra- and postoperative complications in patients.

8. The ability to perceive emotional issues of patients and empathic response to their issues are extremely important vocational skills of nurses and doctors.

9. Appropriate equipment of the operating theatre and new technologies enable safer and faster methods be introduced and enhance treatment quality.

10. Training and continuous development of all professional groups is a guarantee that highest quality is maintained at the operating theatre.
11. Correctly performed disinfection and sterilization effectively eliminate microbial transmission routes linking an infection source with a patient.

12. Surgical material counting is a key element in ensuring patient safety.

13. Nosocomial infections pose a serious threat to patient safety and their effects are a burden for patients' families, society and healthcare systems.

14. Being aware of infections and their sequelae, causes, epidemiology, aetiology and symptoms is a prerequisite for their efficient control and effective prevention.

15. Nosocomial infections can be prevented by introducing an appropriate infection control system, organising inhospital training, and providing staff with access to current medical knowledge.

16. Reporting and analysis of medical errors may help identify major factors that have contributed to their occurrence.

17. The perioperative control chart is a simple, inexpensive and practical way to reduce the number of complications.

18. Actions to reduce the number of medical errors and adverse events must be based on a thorough assessment of their causes and condition in which they took place.

19. All adverse events and medical errors should be recorded, reported and analysed.

\section{REFERENCES}

1. Zaczyk I. Praca źródłem stresu. [http://www.nursing.com.pl/Medinf Praca_rdem_stresu_292.html]

2. Weiser TG, Regenbogen SE, Thompson KD, et al. Anestimation of the global volume of surgery: a model ling strategy based on available data. Lancet. 2008;372:139-44.

3. Lisowska B. Ujawnianie zdarzeń niepożądanych. Puls Medycyny 2005;22.

4. Piątek A. Błędy i wykroczenia w praktyce zawodowej pielęgniarek i położnych a bezpieczeństwo pacjentów. [http://www.zdrowiepubliczne. $\mathrm{pl} /$ artykul/szczegoly/id/1605.]

5. Rozporządzenie Ministra Zdrowia z dnia 11 października 2018 r. zmieniające rozporządzenie $\mathrm{w}$ sprawie świadczeń gwarantowanych $\mathrm{z}$ zakresu leczenia szpitalnego (Dz. U. z 2018 r., poz. 2012).

6. Motyka M. Empatia a studia pielęgniarskie. Sztuka leczenia. 2006;XIII(12):3338.

7. Gwizdak T. Bezpieczeństwo pacjenta w szpitalu. Probl Pielęg. 2008;16(1,2):181-5.

8. Litke J. Lista bezpieczeństwa chirurgicznego - zalecenia Światowej Organizacji Zdrowia. Anestezjol Ratown. 2009;3:254-60.

9. Kryst L. Zdarzenia niepożądane i błędy medyczne w opiece zdrowotnej Bezpieczeństwo Pracy: nauka i praktyka. 2011(11):22-3.

10. Kutaj-Wąsikowska H, Kutryba B. Światowy Sojusz Na Rzecz Bezpieczeństwa Pacjentów, Podstawy wprowadzania okołooperacyjnej karty kontrolnej. Adaptacja na podstawie Implementation Manual Surgical Safety Checklist (First Edition) by World Alliance for Patient Safety. WHO CC Krakow At Centrum Monitorowania w Ochronie Zdrowia. Kraków; 2009.

11. Hanson CW. Procedury w intensywnej terapii. Warszawa: Medmedia; 2009.

12. Kutryba B, Kutaj-Wąsikowska H. Programy bezpieczeństwa. [http://www. $\mathrm{mz}$. gov.pl $/ \mathrm{wwwmz} / \mathrm{index} ? \mathrm{mr}=\mathrm{m} 7 \& \mathrm{~ms}=603 \& \mathrm{ml}=\mathrm{pl} \& \mathrm{mi}=603 \& \mathrm{mx}=0 \& \mathrm{mt}$ $=\& m y=602 \& m a=18078$.]

13. Kutryba B, Kutaj-Wąsikowska H. Bezpieczny pacjent, bezpieczny szpital [http://www.mz.gov.pl/wwwmz/slajd?mr=m7\&ms $=603 \& \mathrm{ml}=\mathrm{pl} \& \mathrm{mi}=603$ $\& m x=0 \& m t=\& m y=602 \& m a=018078$. $]$

14. Pokorski J, Pokorska J, Złowodzki M. Błąd medyczny. Uwarunkowania ergonomiczne. Kraków: Polska Akademia Nauk; 2010.

15. Witczak I. Ryzyko występowania „czarnych punktów” w procesach medycznych bloków operacyjnych w Polsce. Public Health Forum. 2017;3(4):256-62.

16. Wróblewska M, Kawecki D. Dezynfekcja skóry i obłożenie pola operacyjnego. Zakażenia. 2008;4:81-6. 
17. Definicje zakażeń szpitalnych związanych z opieką zdrowotną (HAI) obowiązujące od 1 stycznia 2016r. Narodowy Program Ochrony Antybiotyków. [http://antybiotyki.edu.pl/definicje-zakaz-en-zwiazanych-z-opieka-zdrowotna-hai-obowiazujace-od-1-stycznia-2016-r/]

18. Montewka M, Skrzek A, Plewik D, et al. Zakażenia miejsca operowanego -charakterystyka czynników ryzyka, endogennych źródeł zakażenia i metody zapobiegania. Post Mikrobiol. 2012;51(3):227-35.

19. Gospodarek E, Szopiński J, Mikucka A. Zakażenie miejsca operowanego -postaci kliniczne, czynniki ryzyka, profilaktyka, etiologia, diagnostyka. Forum Zakażeń. 2013;4(5):275-82.

20. Ksykiewicz-Dorota A. Zarządzanie w pielęgniarstwie. Lublin: Wydawnictwo Czelej; 2005. p. 454
Corresponding author

Aldona Michalak

Chair and Department of General and Transplantation Surgery,

Transplantation Institute, Warsaw

59 Nowogrodzka St., 02-006 Warszawa

E-mail: aldonano@o2.pl 